Sains Malaysiana 47(4)(2018): 645-649

http://dx.doi.org/10.17576/jsm-2018-4704-01

\title{
Anatomi Rizom dan Stip Genus Pleocnemia Presl (Tectariaceae) di Semenanjung Malaysia
}

(Anatomy of Rhizomes and Stipes Genus Pleocnemia Presl (Tectariaceae) in Peninsular Malaysia)

\author{
MaideEn, H.,* SyazWani, B., Nik Norhazrina, N.M.K., NuR-Aliah, M.K., Noraini, T. \& NuR FARHANIM, I.
}

ABSTRAK

\begin{abstract}
Kajian anatomi rizom dan stip telah dijalankan ke atas empat spesies Pleocnemia yang terdapat di Semenanjung Malaysia iaitu P. irregularis, P. conjugata, P. hemiteliiformis dan P. olivacea untuk mengkaji variasi ciri yang terdapat pada rizom dan stip ini. Kajian ini melibatkan keratan rentas stip dan rizom dengan menggunakan mikrotom gelongsor. Ciri anatomi stip seperti bentuk luaran, corak kehadiran sel sklerenkima di bawah epidermis, jenis dan bentuk stel dan ciri anatomi rizom seperti kehadiran sel rembes tanin dan kehadiran serta jenis trikom pada sesetengah spesies boleh digunakan untuk pengecaman spesies. Ciri sepunya bagi spesies Pleocnemia yang dikaji ialah kehadiran sel sklerenkima mengelilingi stel dan di bawah lapisan sel epidermis, stel jenis kompleks serta stel bagi kesemua spesies kajian berbentuk protostel primitif (bulat). Antara ciri diagnosis yang ditemui dalam kajian ini ialah bentuk luaran stip, bilangan lapisan skelerenkima di bawah epidermis, kehadiran sel rembes tanin bagi spesies P. irregularis dan P. hemiteliiformis serta kehadiran jenis trikom yang berbeza dalam keempat-empat spesies. Ciri diagnosis ini adalah ciri yang baik untuk pengecaman spesies kajian. Keputusan kajian ini menunjukkan bahawa ciri anatomi stip dan rizom mempunyai nilai taksonomi dalam genus Pleocnemia dan boleh digunakan sebagai data sokongan untuk pengecaman dan pembezaan spesies.
\end{abstract}

Kata kunci: Anatomi; Pleocnemia; protostel primitif; rizom; Semenanjung Malaysia

\section{ABSTRACT}

Anatomical studies of the stipe and rhizome were conducted on four Pleocnemia species recorded in Peninsular Malaysia, namely P. irregularis, P. conjugata, P. hemiteliiformis and P. olivacea to investigate the anatomical variations of the stipe and rhizome. Cross-section of the stipe and rhizome was done using sliding microtome. Stipe anatomical characteristics such as stipe outline, pattern of schlerenchyma cells under epidermal layers, stele types and shapes and rhizome anatomical characteristics such as presence of tanniferous idioblast cells, presence and types of trichomes were useful for species identification. The shared characters in all the Pleocnemia species studied were the presence of schlerenchyma cells below the epidermal layers and surrounding the steles, complex steles shape and primitive protestele (round). Diagnostic characteristics found in this study were stipe outline, number of schlerenchyma cell layers below the epidermal cells, presence of tanniferous idioblast cells in $\mathrm{P}$. irregularis and $\mathrm{P}$. hemiteliiformis and the different types of trichomes in all the four species. These diagnostic characters were useful for identification of the studied species. The present study showed that stipe and rhizome anatomical characteristics have taxonomic value in Pleocnemia and are useful support data for species differentiation and identification.

Keywords: Anatomy; Peninsular Malaysia; Pleocnemia; primitive protostele; rhizome

\section{PENGENALAN}

Anatomi tumbuhan secara keseluruhannya adalah kajian mengenai struktur dalaman seperti sel, tisu dan organ tumbuhan. Ketiga-tiga struktur ini merupakan bahagian tumbuhan yang saling berinteraksi dengan persekitaran. Data yang diperoleh daripada kajian anatomi adalah penting untuk mendapatkan maklumat dan menjelaskan hubungan filogenetik antara spesies (Simpson 2006). Organ tumbuhan yang sering digunakan dalam kajian anatomi adalah bahagian daun kerana bahagian ini mempunyai kepelbagaian variasi yang tinggi jika dibandingkan dengan organ yang lain. Kajian anatomi adalah signifikan dalam bidang taksonomi kerana ciri anatomi boleh membantu dalam proses pengelasan dan pengecaman pada peringkat famili dan genus (Metcalfe \& Chalk 1983). Antara kajian anatomi yang telah terbukti membantu dalam proses pengecaman paku pakis ialah dalam genus Blechnum (Noraini et al. 2014), genus Selaginella (Maideen et al 2013), genus Davallia (Noraini et al. 2012) dan genus Polystichum (Roux \& Van-Wyk 2000).

Tectariaceae merupakan famili paku pakis jenis polipod yang biasanya tumbuh secara terestrial, bersaiz sederhana dan mempunyai rizom tegak atau separa tegak dan bersisik (Liu et al. 2007). Pengelasan bagi famili ini 
masih tidak jelas dan bilangan genus yang diletakkan di bawah famili ini sering berubah-ubah mengikut sistem pengelasan yang berbeza. Holttum (1947) telah meletakkan Tectariaceae ke dalam famili Dennstaedtiaceae sebagai sub-famili Tectarioideae yang terdiri daripada genus Amphiblestra C. Presl, Arcypteris Underw., Ctenitis (C. Chr.) C. Chr., Cyclopeltis J. Sm., Dictyoxiphium Hook., Hemigramma Christ, Heterogonium C. Presl, Lastreopsis Ching, Pleocnemia C. Presl, Pleuroderris Maxon, Pteridrys C. Chr., Quercifilix Copel., Stenosemia C. Presl dan Tectaria Cav. Tectariaceae sensu Ching pula mempunyai anggaran lebih daripada 20 genus dan sekurang-kurangnya 400 spesies yang mempunyai taburan di kawasan pan-tropika di seluruh dunia (Wang 1999).

Genus Pleocnemia mempunyai anggaran 20 spesies, taburan di kawasan tropika Asia, dari Timur Laut India, Tenggara China, hingga ke Malaysia dan Pasifik Barat ke Samoa (Xing et al. 2013). Terdapat empat spesies Pleocnemia yang direkodkan di Semenanjung Malaysia iaitu $P$. irregularis, $P$. conjugata, $P$. hemiteliiformis dan $P$. olivacea. Genus ini pertama kali diperkenalkan oleh Presl (1836) hanya mempunyai satu spesies iaitu Pleocnemia leuzeana, berdasarkan spesies Polypodium leuzeanum. Pengelasan yang telah dilakukan oleh Christenhusz et al. (2011) dan Smith et al. (2006) telah meletakkan genus Pleocnemia ke dalam famili Tectariaceae, manakala Christenhusz dan Chase (2014) dan PPG I. (2016) telah meletakkan genus ini ke dalam famili Dryopteridaceae.

Menurut Holttum (1968), ciri diagnostik pada genus Pleocnemia ialah rizom bersisik, bahagian pangkal stip sangat tirus dan bergigi dan bentuk fron bipinat ke tripinatifik dengan kehadiran gigi pada setiap sinus antara lobus lamina. Rerambut kelenjar berbentuk silinder dan bewarna kuning juga biasanya hadir di bawah permukaan peruratan atau kosta. Pleocnemia dikatakan mempunyai hubungan yang rapat dengan genus Pteridrys dan Arcypteris (Holttum 1951) berdasarkan struktur rakis dan bawah kosta serta kehadiran gigi pada pangkal sinus antara lobus pada pina. Namun demikian, terdapat perbezaan antara ketiga-tiga genus ini dengan Pleocnemia dan Arcypteris mempunyai peruratan jenis anastomos berbanding Pteridrys yang mempunyai peruratan jenis bebas. Arcypteris juga mempunyai fron yang kurang bercabang dan kehadiran kelenjar bewarna merah berbanding Pleocnemia yang mempunyai fron yang lebih bercabang dan kehadiran kelenjar yang bewarna kuning.
Objektif utama kajian ini adalah untuk menentukan variasi dan persamaan ciri anatomi rizom dan stip serta signifikan ciri tersebut pada genus Pleocnemia yang boleh digunakan dalam pengecaman spesies. Kajian ini juga dilakukan kerana tiada kajian anatomi yang komprehansif ke atas stip dan rizom yang pernah dijalankan bagi spesies daripada genus Pleocnemia yang terdapat di Semenanjung Malaysia.

\section{BAHAN DAN KAEDAH}

Sebanyak empat spesies Pleocnemia yang terdapat di Semenanjung Malaysia digunakan dalam kajian ini. Senarai spesimen dan lokasi pengutipan diberikan dalam Jadual 1. Stip daripada spesimen herbarium direbus terlebih dahulu selama 15 min dan kemudiannya ditetapkan dalam larutan penetap AA (alkohol: asid asetik) selama 48 jam sebelum dihiris dengan menggunakan mikrotom gelongsor. Teknik hirisan, pewarnaan, penyahairan dan penyediaan slaid keratan rentas rizom dan stip adalah mengikut teknik yang telah diubah suai daripada kaedah yang telah dicadangkan oleh Johansen (1940) dan Saas (1958).

\section{KEPUTUSAN DAN PERBINCANGAN}

Kajian anatomi rizom dan stip telah dijalankan ke atas empat spesies Pleocnemia yang terdapat di Semenanjung Malaysia iaitu P. irregularis, P. conjugata, P. hemiteliiformis dan P. olivacea. Menurut Ogura (1972) ciri anatomi stip amat sesuai dalam kajian sistematik kerana terdapat variasi pada stel, bentuk dan kehadiran sklerenkima. Stip juga sesuai digunakan dalam kajian anatomi kerana bahagian ini senang diperoleh dan ia kurang dipengaruhi oleh faktor persekitaran.

Ciri anatomi seperti variasi pada stel boleh dilihat dengan melakukan keratan rentas stip pada bahagian atas, tengah dan bawah (Ogura 1972). Dalam kajian ini, jelas terdapat variasi bentuk luaran pada ketiga-tiga bahagian tersebut. Oleh yang demikian, pemerhatian ini telah menyokong kajian yang telah dilakukan oleh Noraini et al. (2012) dan Ogura (1972) yang telah menyatakan bahawa panjang stip sesetengah spesies menunjukkan kepelbagaian variasi corak stel pada bahagian atas, tengah dan bawah dan terdapat juga spesies yang menunjukkan corak yang sama pada ketiga-tiga bahagian.

Beberapa ciri anatomi stip seperti bentuk luaran stip, jenis stel, bentuk stel dan kehadiran skelerenkima boleh

JADUAL 1. Maklumat spesimen Pleocnemia yang dikaji

\begin{tabular}{lclcl}
\hline \multicolumn{1}{c}{ Spesies } & No. Spesimen & \multicolumn{1}{c}{ Lokaliti } & Tarikh & Nama pengumpul \\
\hline $\begin{array}{l}\text { P. } \text { irregularis } \\
\text { P. conjugata }\end{array}$ & NS01 & Sg. Kanching, Rawang & $4 / 12 / 2014$ & Nur Syazwani \\
& NS02 & Robinson Waterfall,Cameron Highland, Pahang & $10 / 12 / 2014$ & $\begin{array}{l}\text { Nur Syazwani, } \\
\text { Samiah Kadri }\end{array}$ \\
P. hemitelifformis & NS03 & Gunung Angsi, Negeri Sembilan & $27 / 12 / 2014$ & $\begin{array}{l}\text { Nur Syazwani, } \\
\text { Samiah Kadri }\end{array}$ \\
P. olivacea & AB1747 & Herbarium Universiti Kebangsaan Malaysia & $19 / 3 / 1983$ & Aziz Bidin, \\
& & & & Razali, \\
& & & Hendon \\
\hline
\end{tabular}


dilihat dalam keempat-empat spesies ini. Keputusan kajian ini menunjukkan terdapat persamaan dan perbezaan dalam ciri anatomi stip bagi $P$. conjugata, $P$. irregularis, $P$. olivacea dan $P$. hemiteliiformis. Ciri sepunya bagi kesemua spesies ialah kehadiran sel sklerenkima di bawah lapisan sel epidermis dan kehadiran stel utama dengan bentuk hipokampus (Onoclea) dan stel tambahan yang berbentuk elip (Marattia). Dalam kajian ini, jumlah lapisan sel sklerenkima adalah antara 7 dan 24 lapisan (Rajah 1(a)-(c)). Keputusan kajian ini jelas menunjukkan bahawa genus Pleocnemia mempunyai struktur stip yang keras dan kuat. Selain itu, kesemua spesies kajian juga mempunyai satu lapisan hitam mengelilingi stel pada keratan rentas stip (Rajah 1(d)-(e)). Menurut Dickison (2000), sel sklerenkima adalah merupakan komponen tisu yang memberi keteguhan dan kekuatan kepada tumbuhan dan juga berfungsi sebagai tisu sokongan. Kesemua spesies kajian mempunyai sel skelerenkima di bawah lapisan epidermis stip dan mengelilingi stel secara selanjar.

Jenis stel juga merupakan salah satu ciri penting anatomi stip. Stel boleh ditakrifkan sebagai organ pengangkutan atau sistem vaskular pteridofit yang mengandungi protoxilem dan metaxilem, salah satu atau kedua-duanya hadir bersama dengan floem (Ogura 1972). Spesies Pleocnemia yang dikaji menunjukkan stel jenis kompleks iaitu terdapat stel utama berbentuk hipokampus dan stel tambahan berbentuk elip. Menurut Ogura (1972), spesies yang berstel kompleks akan mempunyai lebih daripada satu berkas vaskular. Keempat-empat spesies Pleocnemia ini mempunyai bentuk stel yang sama, iaitu protostel primitif (bulat) dan hanya berbeza daripada segi saiz. Menurut Ogura (1972), protostel primitif adalah
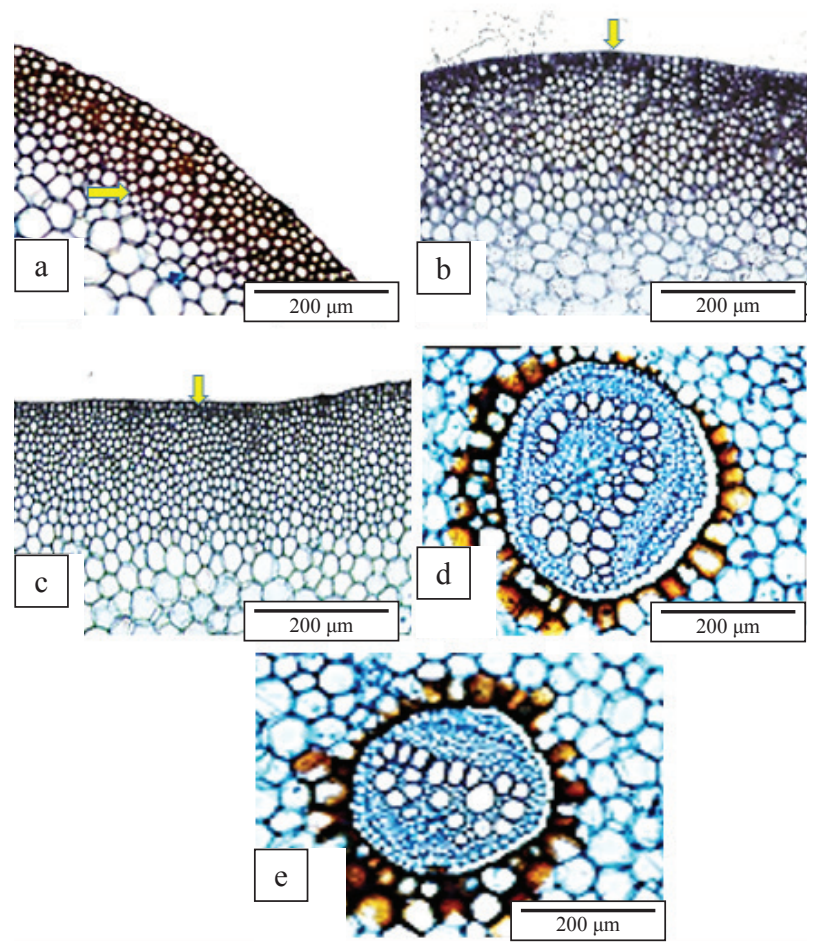

RAJAH 1. Keratan rentas rentas stip (a)-(c) dan lapisan sel sklerenkima bawah epidermis stip (d)-(e). Lapisan sel sklerenkima mengelilingi stel sistem stel yang paling ringkas. Stel jenis ini mempunyai tisu vaskular berpusar dikelilingi oleh endodermis. Stel ini juga merupakan jenis asas sistem tisu vaskular pada nenek moyang kumpulan pteridofit dan dijumpai biasanya dalam pteridofit primitif.

Variasi dalam ciri anatomi stip juga boleh dilihat dalam bentuk luaran keratan rentas stip atas, tengah dan bawah (Rajah 2-4). Bagi memudahkan perbincangan dan perbandingan ciri bentuk luaran stip dihurai berdasarkan dua kategori yang disediakan dalam Jadual 2. Dua bentuk luaran bagi keratan rentas bahagian atas, tengah dan bawah stip dapat dikenal pasti pada keempat-empat spesies kajian. Bentuk luaran bagi $P$. irregularis, $P$. hemiteliiformis dan $P$. olivacea adalah sama iaitu jenis 2 manakala $P$. conjugata mempunyai bentuk luaran jenis 1 . Keputusan kajian jelas
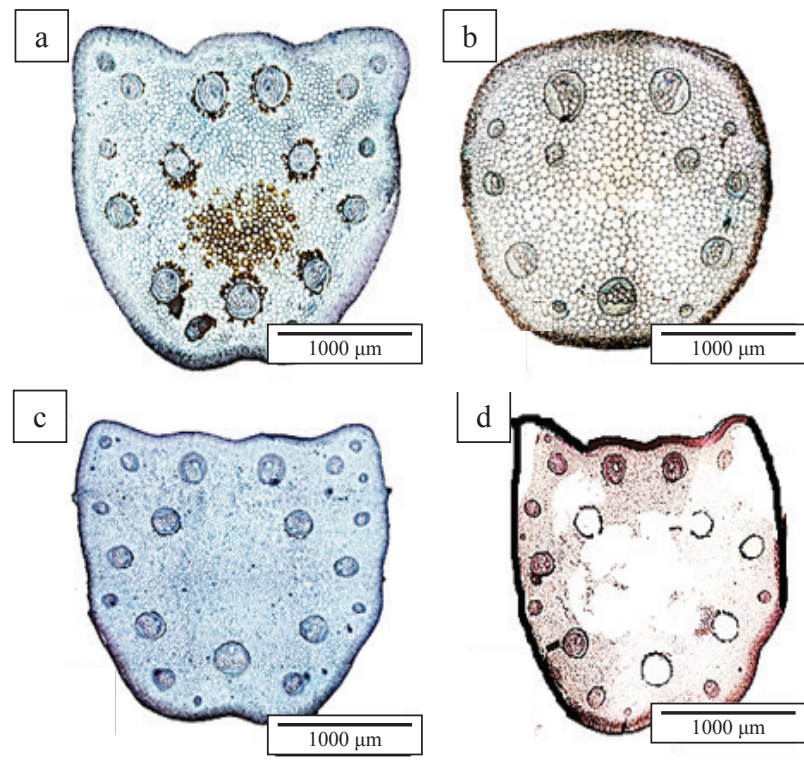

RAJAH 2. Variasi keratan rentas bahagian atas stip (a) P. irregularis, (b) P. conjugata, (c) P. hemiteliiformis dan (d) P. olivacea
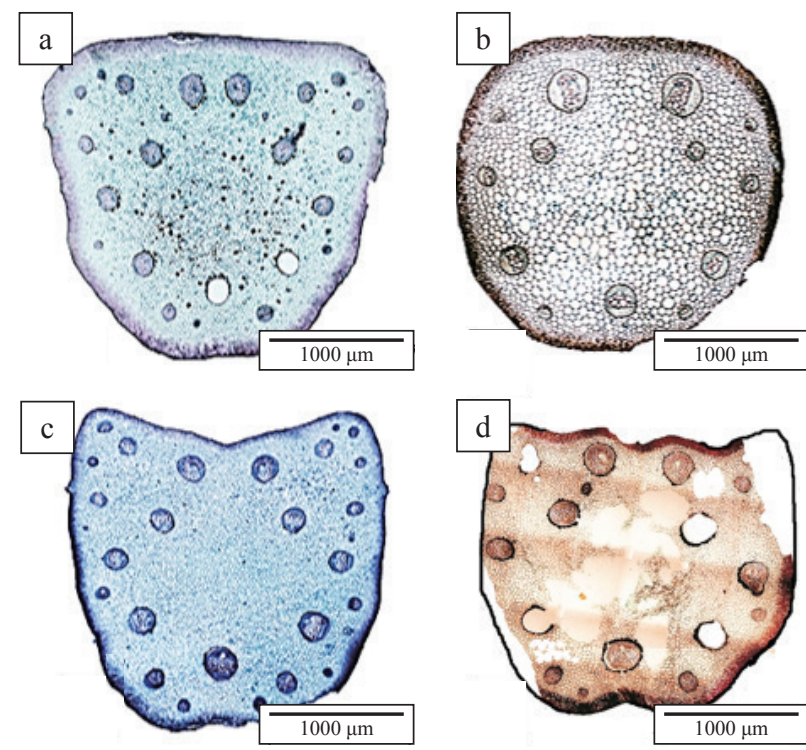

RAJAH 3. Variasi keratan rentas bahagian tengah stip (a) P. irregularis, (b) P. conjugata, (c) P. hemiteliiformis dan (d) P. olivacea 

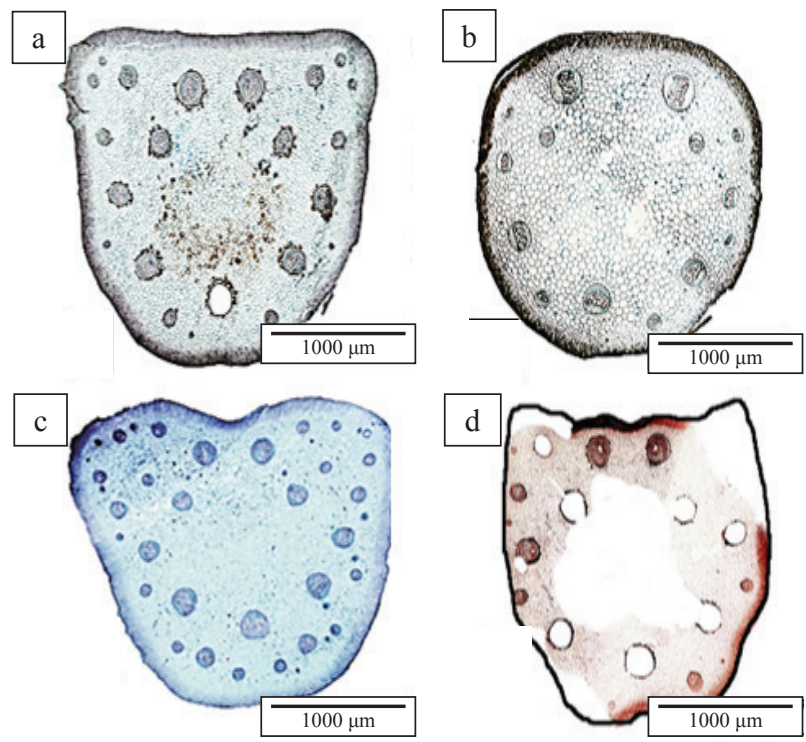

RAJAH 4. Variasi keratan rentas bahagian bawah stip (a) P. irregularis, (b) P. conjugata, (c) P. hemiteliiformis dan (d) P. olivacea

JADUAL 2. Variasi kehadiran lapisan sel sklerenkima pada keratan rentas stip

\begin{tabular}{|c|c|c|}
\hline Ilustrasi & $\begin{array}{l}\text { Bentuk } \\
\text { luaran }\end{array}$ & Huraian kehadiran \\
\hline & 1 & $\begin{array}{l}\text { Beberapa lapisan sel } \\
\text { sklerenkima berada di } \\
\text { bawah lapisan epidermis } \\
\text { secara selanjar }\end{array}$ \\
\hline & 2 & $\begin{array}{l}\text { Beberapa lapisan sel } \\
\text { sklerenkima berada di } \\
\text { bawah lapisan epidermis } \\
\text { secara selanjar meliputi } \\
\text { bahagian cuping tetapi } \\
\text { meninggalkan kelompok } \\
\text { sel parenkima pada } \\
\text { bahagian tengah cuping }\end{array}$ \\
\hline
\end{tabular}

menunjukkan perbezaan bentuk luaran stip bagi spesies $P$. conjugata kecuali bagi ketiga-tiga spesies lain yang memerlukan ciri anatomi lain untuk pembezaan spesies.

Bagi ciri anatomi rizom pula, sel rembes tanin dan trikom jenis ringkas hadir pada $P$. hemiteliiformis dan $P$. irregularis. Namun, $P$. irregularis hanya mempunyai satu lapisan epidermis jika dibandingkan dengan $P$. hemiteliiformis yang mempunyai dua lapisan epidermis. Bagi $P$. olivacea dan P. conjugata pula, sel rembes tidak hadir pada kedua-dua spesies. Trikom jenis ringkas multiseriat hadir pada $P$. conjugata manakala trikom jenis kelenjar peltat hadir pada $P$. olivacea (Rajah 5). Keputusan kajian juga menunjukkan $P$. olivacea mempunyai bilangan lapisan sel sklerenkima yang lebih tebal, iaitu 18 hingga 20 lapisan jika dibandingkan dengan $P$. conjugata yang hanya mempunyai 7 hingga 9 lapisan sel sklerenkima.

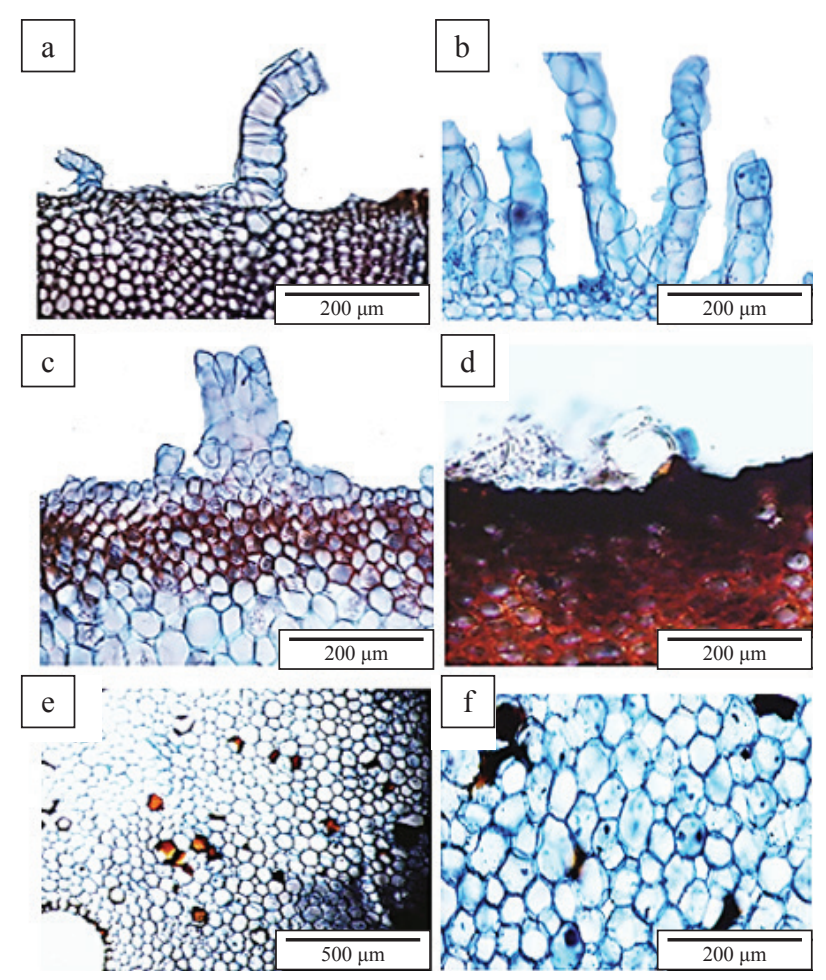

RAJAH 5. Kehadiran pelbagai jenis trikom. Trikom ringkas pada (a) P. irregularis dan (b) P. hemiteliformis; trikom ringkas multiseriat pada (c) P. conjugate; dan trikom kelenjar peltat pada (d) P. olivacea. Kehadiran tanin pada (e) P. irregularis dan (f) P. hemiteliiformis

\section{KESIMPULAN}

Keputusan kajian ke atas ciri anatomi stip dan rizom bagi keempat-empat spesies Pleocnemia di Semenanjung Malaysia iaitu $P$. hemiteliiformis, $P$. conjugata, $P$. irregularis dan $P$. olivacea menunjukkan ciri variasi dan ciri sepunya antara spesies kajian. Terdapat tiga ciri yang boleh digunakan untuk pembezaan dan pengecaman spesies, iaitu bentuk luaran stip, corak kehadiran sel sklerenkima di bawah epidermis, kehadiran trikom serta sel rembes tanin pada keratan rentas rizom. Ciri sepunya bagi kesemua spesies kajian ialah kehadiran sel sklerenkima mengelilingi stel, kehadiran sel sklerenkima di bawah epidermis, jenis stel dan bentuk stel.

Beberapa ciri diagnostik ditemui daripada kajian ini boleh digunakan untuk pengecaman spesies tertentu. Keputusan kajian daripada keratan rentas anatomi rizom menunjukkan kehadiran trikom jenis kelenjar peltat hanya ditemui pada $P$. olivacea manakala trikom jenis ringkas multiseriat hanya pada $P$. conjugata. Kehadiran sel rembes tanin mengelilingi stel dan parenkima korteks hanya terdapat pada $P$. irregularis manakala sel rembes tanin yang hanya mengelilingi parenkima korteks pula hanya terdapat pada $P$. hemiteliiformis. Bagi ciri anatomi stip pula, keputusan kajian jelas menunjukkan perbezaan bentuk luaran stip bagi $P$. conjugata yang mempunyai bentuk luaran Jenis 2 manakala ketiga-tiga spesies lain mempunyai bentuk luaran Jenis 1 . Bagi corak kehadiran sel sklerenkima di bawah epidermis pula, hanya $P$. conjugata yang mempunyai kehadiran 
sel skelerenkima di bawah epidermis kurang daripada 10 lapisan manakala $P$. irregularis, $P$. hemiteliiformis dan $P$. olivacea mempunyai lebih daripada 10 lapisan skelerenkima di bawah epidermis. Selain daripada ciri morfologi, ciri anatomi stip dan rizom telah dibuktikan boleh digunakan untuk membantu dalam pengecaman, pembezaan dan pengelasan spesies Pleocnemia.

\section{RUJUKAN}

Christenhusz, M.J.M. \& Chase, M.W. 2014. Trends and concepts in fern classification. Annals of Botany 113: 571-594.

Christenhusz, M.J.M., Zhang, X.C. \& Schneider, H. 2011. A linear sequence of extant families and genera of lycophytes and ferns. Phytotaxa 19: 7-54.

Dickison, W.C. 2000. Integrative Plant Anatomy. San Diego: Academic Press.

Holttum, R.E. 1968. A Revised Flora of Malaya II, Fern of Malaya. Ed. Ke-2. Singapura: Government Printing.

Holttum, R.E. 1951. The fern-genus Pleocnemia Presl. Reinwardtia 1(2): 171-189.

Holttum, R.E. 1947. A revised classification of Leptosporangiate ferns. The Journal of the Linnean Society Botany 53: 123158.

Johansen, D.A. 1940. Plant Microtechnique. New York: McGrawHill.

Liu, H.M., Zhang, X.C. \& Chen, Z. 2007. Polyphyly of the fern family Tectariaceae sensu Ching: Insights from cpDNA sequence data. Science in China Series C Life Sciences 50: 789-798.

Maideen, H., Hazwani, A.N., Nurfarahain, Z., Damanhuri, A., Noraini, T., Rusea, G., Qistina, L. \& Masnoryante, M. 2013. Systematic significance of stipe anatomy of Selaginella (Selaginellaceae) in Peninsular Malaysia. Sains Malaysiana 42(5): 693-696.

Metcalfe, C.R. \& Chalk, L. 1983. Anatomy of the Dicotyledons. Jilid 2. Ed. Ke-2. Oxford: Clarendron Press.

Noraini, T., Ruzi, A.R., Nadiah, N., Nisa, R.N., Maideen, H. \& Solihani, S.N. 2012. Ciri anatomi stip bagi beberapa spesies Davallia (Davalliaceae) di Malaysia. Sains Malaysiana 41(1): 53-62.
Noraini, T., Amirul-Aiman, A.J., Jaman, R., Nor-Fairuz, A.R., Maideen, H., Damanhuri, A. \& Ruzi, A.R. 2014. Systematic significance of stipe anatomy in Peninsular Malaysian Blechnum L. (Blechnaceae) species. Malaysian Applied Biology 43(2): 119-128.

Ogura, Y. 1972. Comparative Anatomy of the Vegetative Organs of the Pteridophytes. Berlin: Borntraeger.

Presl, C.B. 1836. Tentamen Pteridographiae. Prague: Theophili Hasse.

PPG I. 2016. A community-derived classification for extant lycophytes and ferns. Journal of Systematics and Evolution 54(6): 563-603.

Roux, J.P. \& Van-Wyk, A.E. 2000. Morphology and anatomy of the rhizome and frond in the African species of Polystichum (Pteropsida: Dryopteridaceae). Bothalia 30(1): 57-68.

Saas, J.E. 1958. Botanical Microtechnique. Ed. Ke-3. Iowa: Iowa State University Press.

Simpson, M.G. 2006. Plant Systematics. London: Elsevier Academic Press.

Smith, R.A., Pryer, K.M., Schuettpelz, E., Korall, P., Schneider, H. \& Wolf, P.G. 2006. A classification for extant ferns. Taxon 55: 705-731.

Wang, C.H. 1999. Aspidiaceae. Dlm. Flora Reipublicae Popularis Sinicae, Vol. 6, No. 1, edited by Wu, S.H. Beijing: Science Press. hlm. 1-103.

Xing, F., Yan, Y., Dong, S., Wang, F., Christenhusz, M.J.M. \& Hovenkamp, P. 2013. Tectariaceae. Dlm. Flora of China, vol. 2-3, Lycopodiaceae through Polypodiaceae, edited by Wu, Z., Raven, P.H. \& Hong, D. Beijing: Science Press. hlm. 730-746.

School of Environmental and Natural Resource Sciences

Faculty of Science and Technology

Universiti Kebangsaan Malaysia

43600 UKM Bangi, Selangor Darul Ehsan

Malaysia

*Pengarang untuk surat-menyurat; email: aliahkhaduwi@gmail. com

Diserahkan: 15 Jun 2017

Diterima: 13 Oktober 2017 
